\title{
Effects of Temperature Change on the Physico-Chemical Properties of Sesame Seed Oil
}

\author{
Abdul Ademola Olaleye*, Yahaya Alhaji Adamu, Umar Lawan \\ Department of Chemistry, Federal University Dutse, Dutse, Nigeria \\ Email address: \\ lebdul@yahoo.com (A. A. Olaleye) \\ ${ }^{*}$ Corresponding author \\ To cite this article: \\ Abdul AdemolaOlaleye, YahayaAlhajiAdamu, Umar Lawan. Effects of Temperature Change on the Physico-Chemical Properties of Sesame \\ Seed Oil. Science Journal of Analytical Chemistry. Vol. 7, No. 1, 2019, pp. 13-20. doi: 10.11648/j.sjac.20190701.12
}

Received: January 22, 2019; Accepted: February 26, 2019; Published: April 1, 2019

\begin{abstract}
Heating is one of the most commonly used methods of food preparation in homes and industries and prolong use of oil for this purpose causes changes in its physical and chemical properties. The effects of changing temperature on various chemical and physical characteristics of sesame seed oil were studied. The oil was extracted using soxhlet apparatus with nhexane as extraction solvent. The seeds of sesame (Sesamumindicum) were found to have high oil content. Both the chemical and physical characteristics were investigated within a temperature range of $25-290^{\circ} \mathrm{C}$. At room temperature $\left(25^{\circ} \mathrm{C}\right)$, the results revealed the chemical characteristics as follows: acid value (AV) $(5.61 \mathrm{mg} / \mathrm{g})$; peroxide value (PV) $(4.42 \mathrm{Meq} / \mathrm{kg})$; free fatty acid (FFA) (5.89\%). The physical characteristics were: moisture content (MC) $(5.50 \%)$; density $\left(0.99 \mathrm{~g} / \mathrm{cm}^{3}\right)$; refractive index (RI) (1.47). At elevated range of temperatures $\left(170-290^{\circ} \mathrm{C}\right)$, there were corresponding changes in both chemical and physical parameters as follows: AV (5.61-5.91mg/g); PV (4.44-6.05 Meq/kg); FFA (5.91-6.06\%); MC (3.98-0.71\%); density (0.95$\left.0.69 \mathrm{~g} / \mathrm{cm}^{3}\right)$; RI $(1.46-1.40)$. The study showed that there was gradual increase in chemical properties with increase in temperature whereas, the physical properties decreased gradually with increase in temperature.
\end{abstract}

Keywords: Temperature Change, Physico-Chemical Parameters, Sesame Seed Oil

\section{Introduction}

Sesame (Sesamumindicum) is a flowering plant in the kingdom Plantae, Order Lamiales, Family Pedaliaceae, Genus Sesamumand Species indicum. Sesame is an annual shrub with white bell-shaped flowers with a hint of blue, red or yellow with or without branches [1]. Sesame fruits are a capsule with dimensions; $2-5 \mathrm{~cm}$ long and $0.5-2 \mathrm{~cm}$ in diameter. The capsule may have 4-8 rows of seeds in each sesame fruit capsule [2]. Sesame is a fairly high in value food crop, being harvested both for whole seed used in baking, and for the cooking oil extracted from the seed. It is grown for the production of seeds that are rich in oil content. It comes in a variety of colors, from creamy-white to charcoalblack.

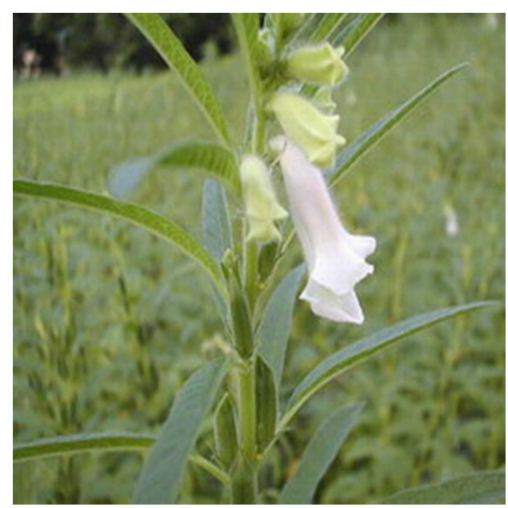

Figure 1. Sesame plant (Sesamumindicum).

In general, the paler varieties of sesame seem to be more valued in West Africa and Middle East, while the black varieties are prized in the far East. Sesame is found in tropical, subtropical, and southern temperate areas of the world, particularly in India, china, south America and Africa. It has utmost economic importance and is primarily grown by 
small farmers in developing countries. Sesame is a tropical herbaceous annual plant that grows 1-2 $\mathrm{m}$ tall, the plant has an unpleasant odour and the leaves vary from ovate to lanceolate and are hairy on both sides. The flowers are purple to whitish, resembling foxglove, followed by $3 \mathrm{~cm}$ capsules/fruits containing numerous seeds [3].

Sesamumindicum is an oilseed with a chemical composition of about $50-52 \%$ oil, $17-19 \%$ protein and $16-18 \%$ carbohydrate. The hull contains large quantities of oxalic acid, crude fiber, calcium and other minerals. When the seed is properly defueled, the oxalic acid content is reduced from about $3 \%$ to less than $0.25 \%$ of the seed weight [4]. Sesame seeds are used in various food items, as a flavoring ingredient They are also known for their nutritional values, as well as therapeutic properties [5]. There are a number of health benefits of sesame seeds, which can be enjoyed by making them a part of your daily diet. They possess a plethora of nutrients that are extremely beneficial for overall human health [6]. Sesame oil comes from sesame seeds, but the composition of the oil depends on the kind of sesame seeds. There are black, white, and brown seeds. But in general, sesame oil consists of about $80 \%$ oleic and linoleic acids. A lot of other vegetable oils are also rich in these two unsaturated fatty acids but sesame oil is unique because it contains approximately equal proportions of the two [7].

Seeds are important source of nutritional oil in industries and pharmaceuticals. The characteristics of oils from different sources depend mainly on their compositions and no oil from a single source can be suitable for all purposes [8]. Seed oils are known to deteriorate when processed inadequately with the principal decomposition reaction being oxidation. Oxidation of seed oil occurs through a free radical mechanism, initially characterized by the emergence of a sweetish and unpleasant odour which becomes progressively worse until it attains a characteristic smell of rancid fat. Heating is one of the most commonly used methods of food preparation in homes and industries and prolong use of oil for this purpose may cause change in its physical and chemical properties [9]. Under the influence of temperature, fat and oils are susceptible to oxidation primarily leading to the formation of hydroperoxides. Due to their high reactivity, these hydroperoxides especially at high temperatures rapidly react with secondary oxidative products e.g. aldehydes, ketones, peroxides, hydrocarbons as well as cyclic compounds that may exhibit very different possible toxic or carcinogenic properties [10]. The products formed during this oxidative process can be determined by chemical analysis and one of the frequently used tests employed to predict the quality of seed oils is the determination of peroxide value and iodine value.

A number of seed oils have been characterized but the vast majority has not been adequately evaluated. Sesame seeds oil is one of the seed oils currently gaining much attention and recognition in homes and industries where it is regularly being subjected to various heating processes. This research work therefore presents the effects of temperature change on the physicochemical properties of sesame seed oil. It is expected to further enhance its usefulness in Food industry.

\section{Materials and Methods}

\subsection{Sample Collection and Preparation}

Fresh sesame seeds were obtained from Babura town in Jigawa State. The seeds were screened to remove stones, sands and defective ones. They were soaked in tap water overnight. Then, the seeds were dried at $60^{\circ} \mathrm{C}$ overnight. The dried seeds were grinded using mortar and pestle. The grinded seeds were dried at $45^{\circ} \mathrm{C}$ overnight.

\subsection{Oil Extraction by Soxhlet Method}

Soxhletextraction method is the most commonly used semi-continuous process for the extraction of oil from foods. As according to Soxhlet procedure, oil was extracted by repeated washing (percolation) with an organic solvent (hexane). The ground sesame seeds samples were placed in a porous cellulose thimble. The thimble was then placed in an extraction chamber which was suspended above a flask containing the solvent and below a condenser. Heat was supplied to the flask, the solvent was evaporated and moved to the condenser where it was converted into liquid and trickled into the extraction chamber containing the sample. The flask containing solvent and oil was then removed at the end of the extraction process. After extraction and evaporation, then the extracted seed oil was stored in a freezer for subsequent physio-chemical analysis.

Percentage yield (\% yield)

$$
\% \text { yield }=\frac{W_{1}-W_{2}}{W_{1}} \times 100
$$

$\mathrm{W}_{1}=$ Weight of the seeds before extraction

$\mathrm{W}_{2}=$ Weight of the seeds after extraction

\subsection{Chemical Analysis}

\subsubsection{Determination of Acid Value}

Acid value was determined according to AOAC [11] method. $1.5 \mathrm{~g}$ of the oil was weighed into $250 \mathrm{ml}$ conical flask and $50 \mathrm{ml}$ of freshly neutralized ethyl alcohol was added followed by $1 \mathrm{ml}$ of phenolphthalein indicator solution. The mixture was boiled for about five minutes and titrated while hot against $0.5 \mathrm{~N}$ potassium hydroxide solution, the mixture was shaken vigorously during the titration.

Calculation:

$$
\text { Acid value }=\frac{56.1 \times \mathrm{V} \times \mathrm{N}}{\text { Sample weight }}
$$

Where,

$\mathrm{V}=$ Volume in $\mathrm{ml}$ of standard potassium hydroxide used

$\mathrm{N}=$ Normality of the potassium hydroxide solution and

\subsubsection{Determination of Peroxide Value}

Peroxide value was determined according to AOAC [12] method. One gramme $(1 \mathrm{~g})$ of oil sample was added to $1 \mathrm{~g}$ of potassium iodide and $20 \mathrm{ml}$ glacial acetic acid:chloroform 2:1. It was then boiled for $1 \mathrm{~min}$. The hot solution was transferred into a flask containing $20 \mathrm{ml}$ of $5 \%$ potassium iodide solution. 
Few drops of starch solution were added and titrated with 0.025 sodium thiosulphate to a faint yellow colour. One millilitre $(1 \mathrm{ml})$ of starch indicator was added and the titration continued until the blue colour disappears.

Calculation:

$$
\text { Peroxide value }=\frac{\text { Titre } \times \text { NX } 100}{\text { Sample weight }}
$$

Where

Titre $=\mathrm{ml}$ of Sodium thiosulphate used (blank corrected)

$\mathrm{N}=$ Normality of sodium thiosulphate solution.

\subsubsection{Free Fatty Acid (FFA)}

Free fatty acid value was determined according to AOAC [13] method. Five grammes $(5 \mathrm{~g})$ of the oil sample was poured into a conical flask. $50 \mathrm{ml}$ of hot alcohol was added with a few drops of phenolphthalein and shaken vigorously. The solution was titrated with $0.5 \mathrm{M}$ sodium hydroxide $(\mathrm{NaOH})$ solution with constant shaking until the pink colour remains constant. From the quantity of $0.5 \mathrm{M}$ alkali used, the percentage of acid present was calculated.

$$
\text { FFA }=\frac{\text { Titre }+ \text { Molar concentrationof } \mathrm{NaOH}+28.2}{\text { Weight of the sample }}
$$

\subsection{Physical Analysis}

\subsubsection{Moisture Content}

Moisture content was determined according to AOAC [13] method. Two grammes $(2 \mathrm{~g})$ of oil sample was weighed and dried in a dish. The lid of the dish was heated in an oven at $105^{\circ} \mathrm{C}$ for 3 hours. The dish was then removed from the oven and the lid was closed and cooled in a desiccator containing phosphorus pentoxide desiccant and weighed. It was heated in the oven for a further period of 1 hour, then cooled and weighed again. The process was repeated up to the point where the reading was constant. The determination was carried out in duplicate.

Calculation

$$
\text { Moisture }(\%)=\frac{\mathrm{w} 1}{W} X 100
$$

Where

$\mathrm{W} 1=$ loss in gm of the sample on drying
$\mathrm{W}=$ original weight in gm of the sample.

\subsubsection{Determination of Density}

The density was determined by the method described by A.O.A.C [11]. Density bottle was cleaned and dried in an oven. Then, it was cooled in a desiccator. The weight of the density bottle was obtained as $\mathrm{W}_{1}$, then the density bottle was filled with oil and the weight of the bottle plus the oil obtained as $\mathrm{W}_{3}$. Then the weight of the oil was obtained by subtracting $\mathrm{W}_{1}$ from $\mathrm{W}_{3}$ and was recorded as $\mathrm{W}_{2}$. The volume of oil was then obtained and recorded. The density of the extracted oil was calculated as follows:

$$
\text { Density }\left(\mathrm{g} / \mathrm{cm}^{3}\right)=\frac{\text { weight of oil }\left(W_{2}\right)}{\text { volume of oil }}
$$

\subsubsection{Determination of Refractive Index}

The sample was filtered through a filter paper to which the impurities and traces of moisture were removed. A stream of water was circulated through the refractometer. The temperature of the refractometer was adjusted. A few drops of the sample were placed on dry and clean prism. The prism was closed and allowed to stand for 2 minutes. The instrument was adjusted and lighted to which the most distinct reading possible was obtained and the refractive index was determined.

\section{Results}

Percentage yield (\% yield)

$$
\% \text { yield }=\frac{W_{1}-W_{2}}{W_{1}} \times 100
$$

Where,

$\mathrm{W}_{1}=$ Weight of the seeds before extraction

$\mathrm{W}_{2}=$ Weight of the seeds after extraction

$$
\% \text { yield }=\frac{(200-93.4) \mathrm{g}}{200 \mathrm{~g}} \times 100=\frac{106.6 \mathrm{~g}}{200 \mathrm{~g}} \times 100=53.3 \%
$$

Some chemical and physical properties of oil extracted

\begin{tabular}{|c|c|c|c|}
\hline $\mathrm{T}\left({ }^{\circ} \mathrm{C}\right)$ & Moisture content (\%) & Density $\left(\mathrm{g} / \mathrm{cm}^{3}\right)$ & Refractive index \\
\hline 25 & $5.500 \pm 0.050$ & $0.990 \pm 0.090$ & $1.470 \pm 0.013$ \\
\hline 170 & $3.980 \pm 0.020$ & $0.950 \pm 0.020$ & $1.460 \pm 0.007$ \\
\hline 200 & $2.080 \pm 0.100$ & $0.930 \pm 0.040$ & $1.430 \pm 0.009$ \\
\hline 230 & $0.770 \pm 0.040$ & $0.860 \pm 0.070$ & $1.410 \pm 0.010$ \\
\hline 260 & $0.730 \pm 0.010$ & $0.800 \pm 0.030$ & $1.400 \pm 0.013$ \\
\hline 290 & $0.710 \pm 0.030$ & $0.690 \pm 0.010$ & $1.400 \pm 0.008$ \\
\hline
\end{tabular}
from sesame seeds (Sesamumindicum) are shown in Tables 1 and 2 respectively.

Table 1. Chemical characteristics of sesame oil heated at different temperatures.

\begin{tabular}{llll}
\hline $\mathbf{T}\left({ }^{\circ} \mathbf{C}\right)$ & Acid value $(\mathbf{m g} / \mathbf{g})$ & Peroxide value( Meq/kg) & Free fatty acid $(\mathbf{\%})$ \\
\hline 25 & $5.610 \pm 0.050$ & $4.420 \pm 0.020$ & $5.890 \pm 0.100$ \\
170 & $5.610 \pm 0.050$ & $4.440 \pm 0.050$ & $5.910 \pm 0.130$ \\
200 & $5.890 \pm 0.030$ & $5.220 \pm 0.100$ & $5.980 \pm 0.070$ \\
230 & $6.135 \pm 0.060$ & $5.540 \pm 0.100$ & $6.030 \pm 0.050$ \\
260 & $6.536 \pm 0.100$ & $6.000 \pm 0.090$ & $6.040 \pm 0.090$ \\
290 & $6.547 \pm 0.090$ & $6.050 \pm 0.007$ & $6.060 \pm 0.120$ \\
\hline
\end{tabular}

Table 2. Physical characteristics of sesame oil heated at different temperatures. 


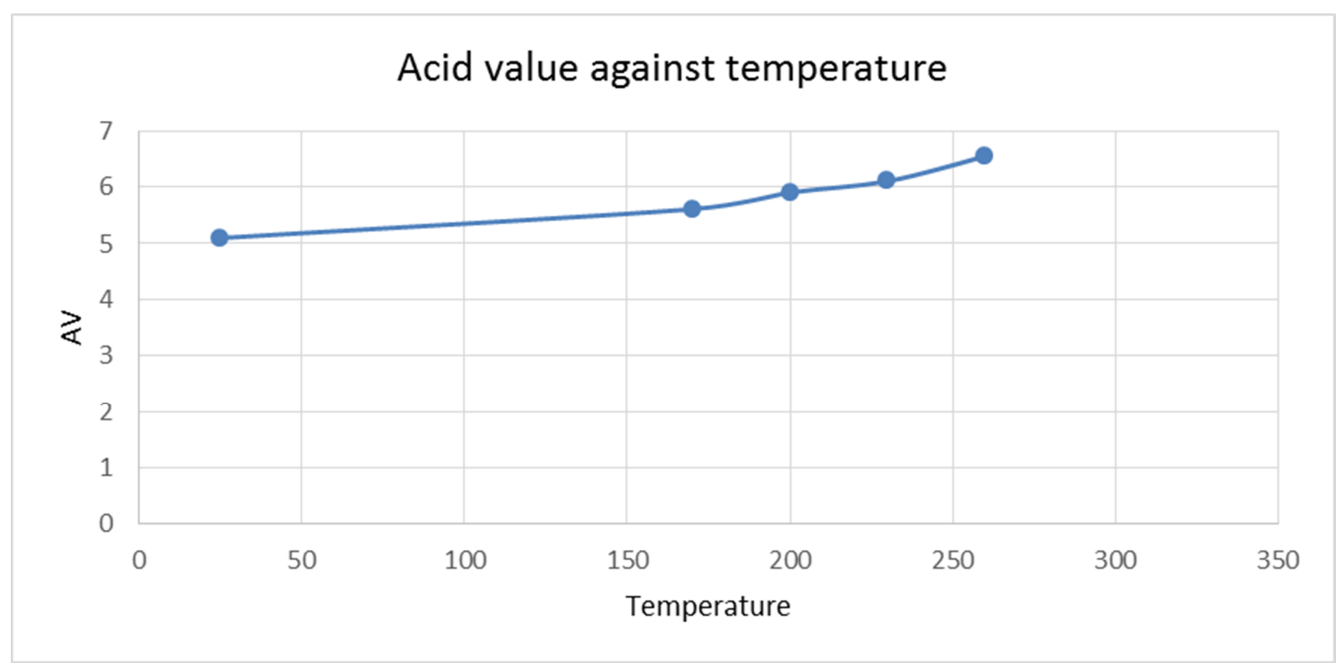

Figure 2. Change in acid value with temperature.

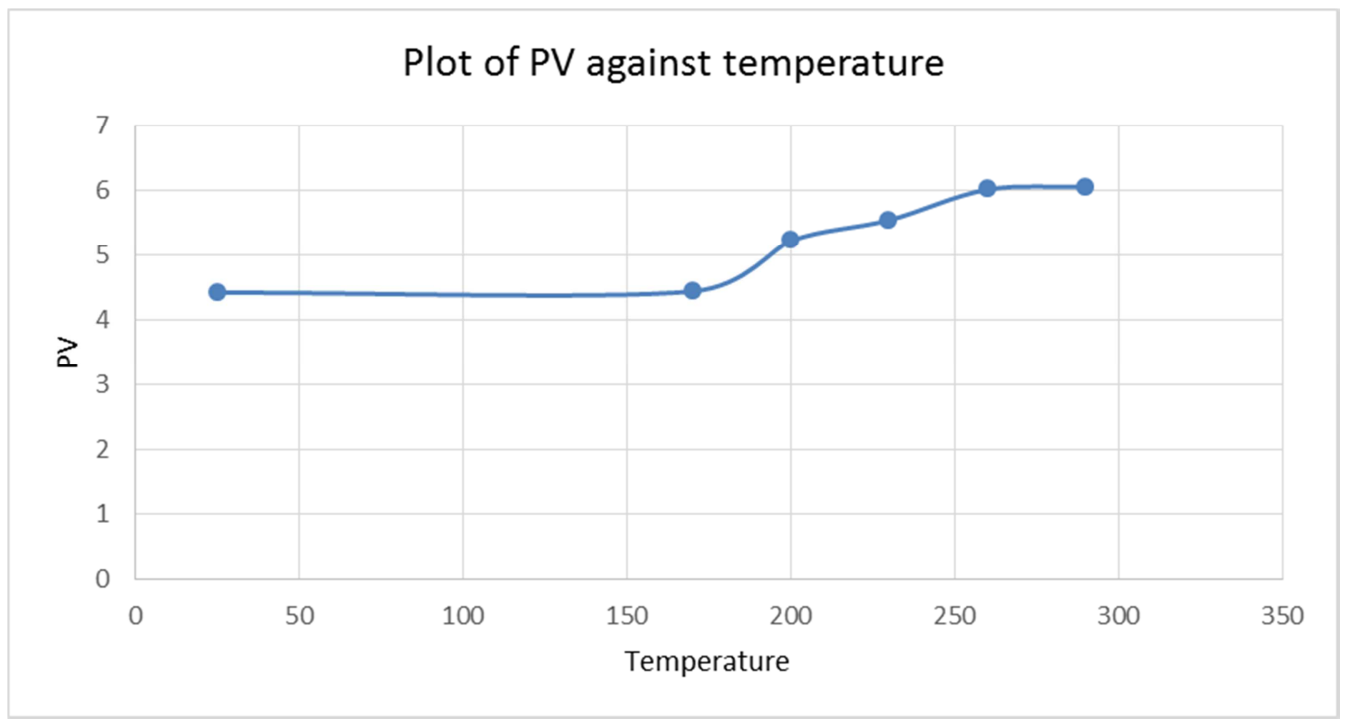

Figure 3. Change in peroxide value with temperature.

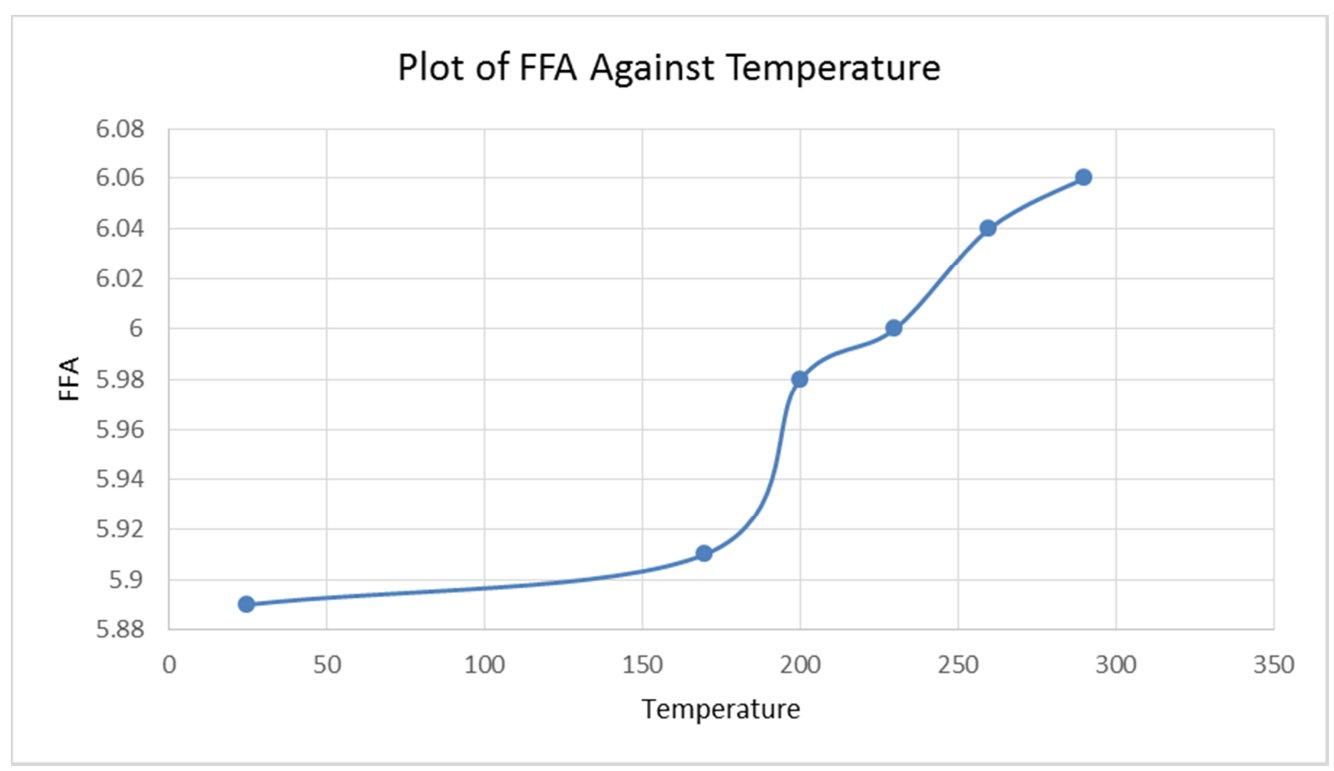

Figure 4. Change in FFA with temperature change. 


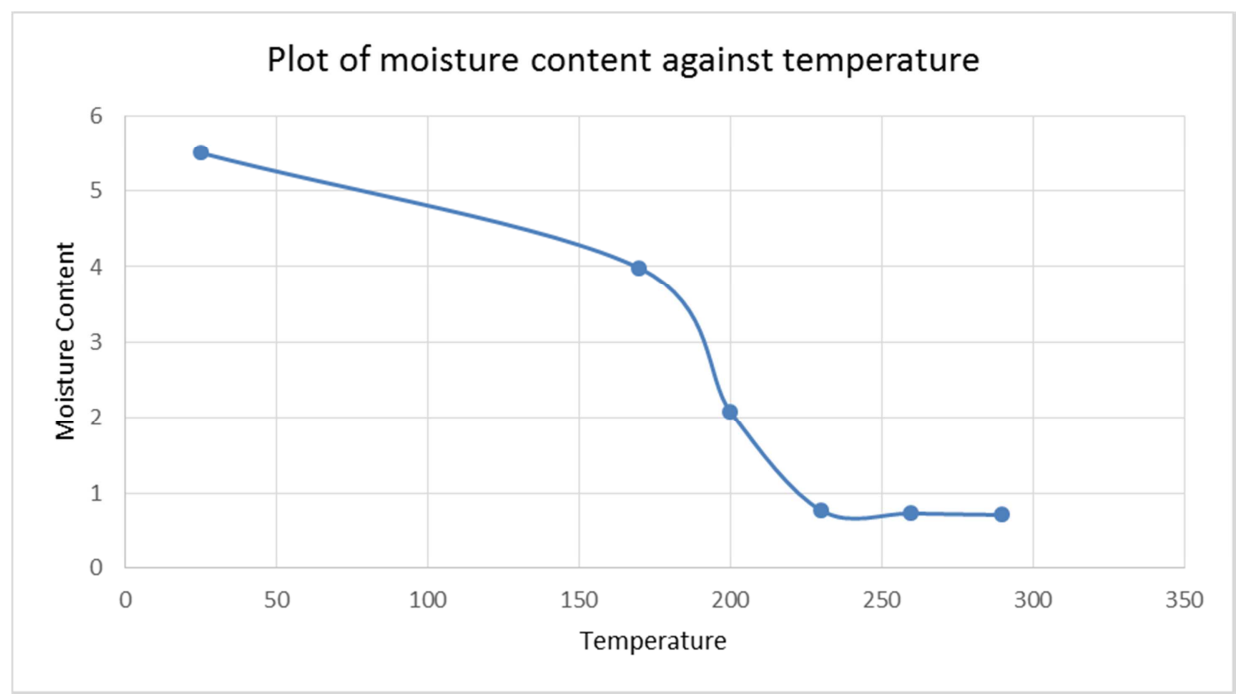

Figure 5. Change in moisture content with temperature.

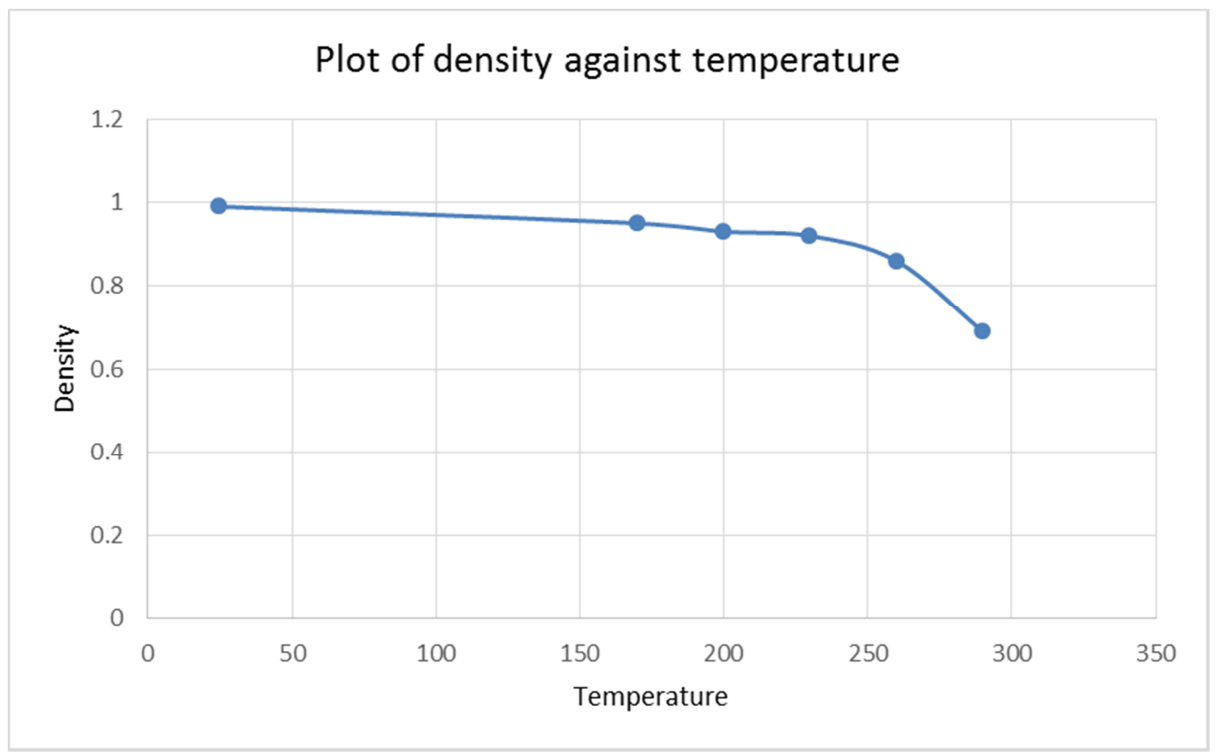

Figure 6. Change in density with temperature.

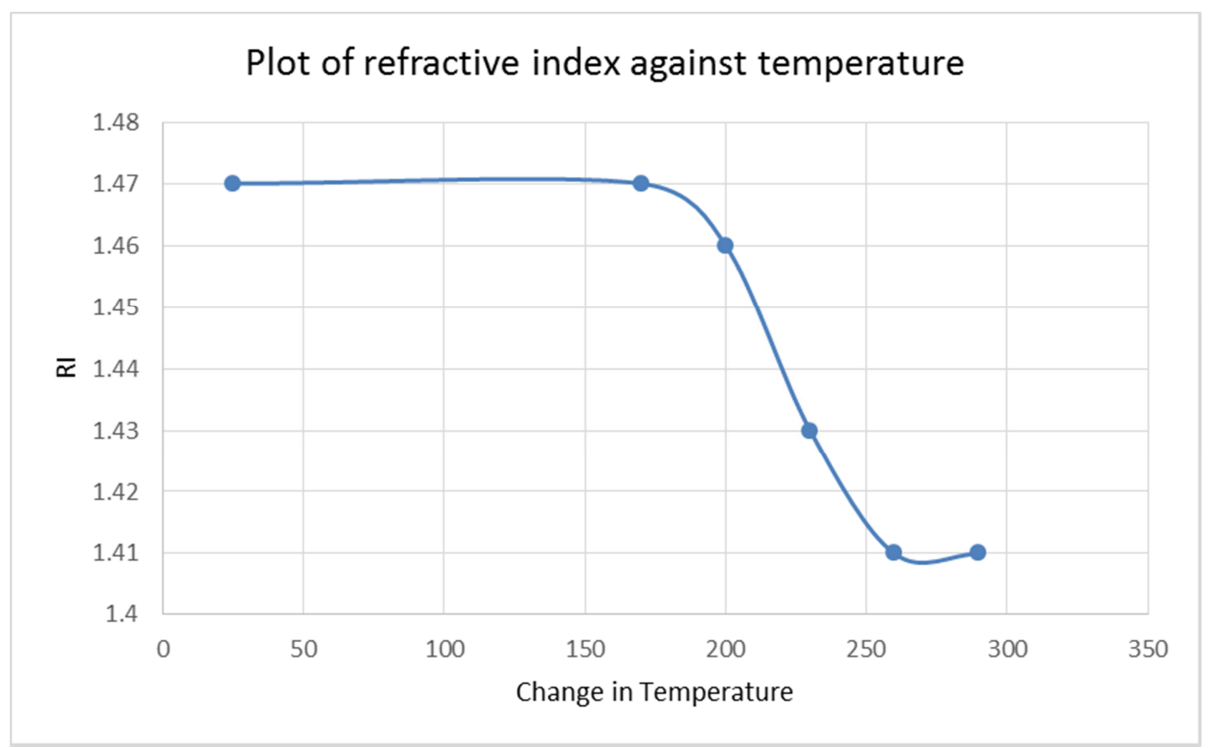

Figure 7. Change in refractive index with temperature. 


\section{Discussion}

\subsection{Percent Yield}

The oil from sesame seeds was extracted using normal hexane as a solvent by soxhlet apparatus. The oil has a gold color, free of haziness, oily liquid at room temperature with slight odour. The level of oil yield obtained in this study $(53.3 \%)$ was higher than $44-51 \%$ obtained in groundnut seeds[14]. This study was also higher than $48 \%$ oilreported by [15] $47.8 \%$ oil by Saeed and Shola [16]for similar sample.

\subsection{Acid Value}

The acid value is an indication of the amount of fatty acid present in the oil sample. The suitability of any seed oil for any direct consumption or industrial application depends on its acid value [17]. The amount in $\mathrm{mg}$ of potassium hydroxide $(\mathrm{KOH})$ required to neutralize the free fatty acid present in $1 \mathrm{~g}$ of fats or oils is known as acid values. The acid values are also used to express the quantity of free fatty acid present in the oils and the determination is often used as a general indication of the condition and edible of oil. It means the higher the number of free fatty acid, the higher the acid value of the oil and vice versa. Normally, fatty acids are found in the triglyceride form, however, during processing the fatty acids may get hydrolyzed into free fatty acid. The higher the acid value found, the higher the level of FFA which translates into decreased oil quality.

Over the tested temperature range $\left(25-290^{\circ} \mathrm{C}\right)$, acid value of minimum (5.61) and maximum $(6.55 \mathrm{mgKOH} / \mathrm{g})$ were recorded. From fig labove, it is shown that heating sesame oil up to a temperature of $170^{\circ} \mathrm{C}$ does not affects its acid value, but when the oil is heated to $200^{\circ} \mathrm{C}$, then the acid value increased, this suggested that as the operating temperature was raised high, acid value started to increase. Increasing acid value is an indication of deterioration of seeds oil, as demonstrated by the increase in degradation of chemical bonds in the oils at higher temperatures. The acid value in this study was slightly higher than the value reported by Godwin et al. (2015) $(5.00 \mathrm{mg} / \mathrm{g})$ at room temperature for palm oil. However, it was lower than $10.7 \mathrm{mg} / \mathrm{g}$ reported by Evbuowmanet al. [18] for cashew nut seed oil.

\subsection{Free Fatty Acid (FFA)}

Free fatty acid is considered to be the percentage by weight of a specified fatty acid [16]. The free fatty acid was also found to be $5.89 \pm 0.10$. The level of FFA in this report was found to increase with increase in temperature. The level of FFA at room temperature in this study was above the following literature values $(\%)$ : varieties of melon seed oil (3.30-3.80) [20], groundnut seed oil (2.33) [21]; castor seed oil $(0.14)$ [22]. High percentage of free fatty acid in oils is undesirable as it can cause off flavour, shorten the shelf life and lower the smoke point of oils Quality of oils is determined by the levels of FFA; oils of good quality have low levels of free fatty acids.

\subsection{Peroxide Value (PV)}

Peroxide value is a measure of oxidation or rancidity [23]. The peroxide value is a useful indicator of the early stages of rancidity occurring under mild conditions and it is a measure of primary lipid oxidation products [24]. It also gives a measure of the extent to which an oil sample has undergone primary oxidation while the extent of secondary oxidation may be determined by $\mathrm{p}$-anisidine test [25]. The peroxide values of sesame oils were presented in Table 1 . Both at room and elevated temperatures, the peroxide value of sesame oil was found to be within the range suggested by Akinoso et al. [4] (3.90-15.4 meq $/ \mathrm{kg})$ for oil obtained from Nigerian varieties. Despite the increase in the PV at high temperatures, the value did not exceed the maximum level of $10 \mathrm{Meq} / \mathrm{kg}$ such that hydrolytic and lipolytic activities became increasingly as suggested by the Codex Alimentarius Commission [26]. The increase in PV is, however, not acceptable since this is a reflection of deteriorating oil quality [27].

\subsection{Density}

From the definition, density of a substance is the ratio of its mass to its volume. Density of seed/vegetable oil is dependent on their fatty acid composition, minor components and temperature [28]. From Table 2 above the density of sesame seed was found to be $0.99 \pm 0.09$ (at room temperature) and decreases with increase in temperature up to $0.69 \pm 0.01$ at $290^{\circ} \mathrm{C}$, this decrease in density with temperature might be due expansion of oil on heating. However, the density value of sesame oil in this study was higher than 0.847 reported for cotton seed oil [29] but lower than 1.16 in cashew nut seed [30]. The difference in density levels between seseme seed oil in this report compared to other sample might be due to variation in fatty acid composition and presence of minor components [28]

\subsection{Refractive Index}

Refractive index (RI) of oil is the ratio of the speed of light at a defined wavelength to its speed in the oil itself. Refractive index varies with variation in the wavelength, temperature, degree and type of unsaturation, the type of substitutions of component fatty acid and accompanying substances. Refractive index is widely used in evaluating the quality control, to check for the purity of materials and to follow hydrogenation and isomerization [31]. From Table 2 above, the refractive Index of sesame oil was found to be $1.47 \pm 0.013$ at room temperature which is within the Codex standard requirements. But when heated, the RI decreases slightly down to $1.40 \pm 0.008$ (at $290^{\circ} \mathrm{C}$ ) this indicates that, refractive index of sesame oil is not stable at elevated temperatures. The result of RI at room temperature in this study agrees with the following literature values: white and yellow melon seed oil (1.47) $[32 ; 33 ; 34]$ and higher than 
0.256 obtained from groundnut seed oil [35].

\section{Conclusion}

The results of this study revealed that sesame seed is high in oil yield. The proximate values indicate it is adequate for both nutrition and health benefits. The peroxide value, acid value and free fatty acid of the oil increased as the temperature increased, while the moisture, density and refractive index decreased as the temperature increased, this implies that sesame seed oil is not stable above the frying temperature $\left(170-190^{\circ} \mathrm{C}\right)$. According to this study, it should be noted that heating sesame oil above $190^{\circ} \mathrm{C}$ makes the oil rancid leading to the formation of hydroperoxides. The difference in the chemical characteristics of sesame oil with change in temperature might be due to the breakdown of primary oxidation products including hydroperoxide into smaller stable fragments, such as carbonyl compounds, alcohols and hydrocarbons.

\section{References}

[1] Martin, J. H. \& Leonard, W. H. (1967). Miscellaneous industries crops. In: Principles of field crop production. Macmillan, New York, Pp. 922-924.

[2] Hwang, L. S. (2005). Vegetable Oils (ed) in Bailey's Industrial Oil and fat products, 6th Edition, Vol.1. Edited by Fereidoon Shahidi. John Wiley \& Sons, Inc, p. 1178.

[3] McCormick Sesame Seeds (Sesamumindicum). (2001). Consumer products. www.mccormick.com/retail.nsf/4c144.

[4] Akinoso, R., Aboaba, S. A. \& Olayanju, T. M. A. (2010). Effects of Moisture Content and Heat Treatment on Peroxide Value and Oxidative Stability of Un-Refined Sesame Oil. AJFAND, 10 (10), 4268-42850

[5] Mohamed, H. M. A \& Awatif, I. I. (1998). The use of sesame oil unsaponifiable matter as natural antioxidant. Food Chem, 62, 269-276.

[6] Aruoma, O. I. (1988). Free radicals, oxidative stress and antioxidants in human health and disease. J Am Oil ChemSoc, 7, 199-212.

[7] Jinyoung, L., Yoosung, L \&Eunok, C. (2008). Effects of sesamol, sesamin, and sesamolin extracted from roasted sesame oil on the thermal oxidation of methyl linoleate. Food SciTechnol, 41, 1871-1875.

[8] Mohammed, R. F. \&Jorf-Thomas, M. (2003). Determination of the lipid classes and fatty acid profile of Niger seed (Guizotiaabyssinica Cass). Phytochem. Anal, 14, 366-370.

[9] Morette, E. Fett, R. (1998). Oils and Food Technology in Industrial Station of Purification. Sao Paulo, Varele.

[10] Kowalki, B. (1995). Determination of oxidative stability of edible vegetable oil by Pressure differential scanning calorimetry. Thermo ChimActa, 250, 197-205.

[11] AOAC. (2000). Official method of analysis, 17th edn, Oil and Fats - Preparation of test sample, 920. 159-Iodine absorption number of oils and fats/I. S. I. Handbook of FoodAnalysis
(Part XIII) -1984 p. 76.

[12] AOAC. (2000). Official nethod of analysis, 17th edn, Peroxide Value in Oils and Fats/Pearsons Composition and Analysis of Foods 9th edn, p 641.

[13] AOAC. (1997). Association of Official Analytical Chemist. Official method of Analysis $17^{\text {th }}$ editionWashington DC.

[14] Savage, G. P., Keenan, J. I. (1994). The composition value of groundnut kernels, In: Smart, J. (ed): The groundnut crop: scientific basis for improvement. Loondon: Chapman and Hall, pp 173-213.

[15] Eze, S. O. O. (2012). Physico-chemical properties of oil from some selectedunderutilized oil seedsavailable for biodiesel preparation. African Journal of Biotechnology, 11 (42), 10003-10007.

[16] Saeed, M. D. \& Shola, E. A. (2015). Extraction and physicchemical properties of some edible seed oils sampled in Kano metropolis, Kano State. Bayero Journal of Pure and Applied Sciences, 8 (2), 239-244.

[17] Al-Bachir, M. (2015). Quality characteristics of oil extracted from gamma irradiated peanut (Arachis hypogea L.). Radiation Physics and Chem., 106, 56-60.

[18] Evbuowman, B. O., Lawson, J. N. \& Atuka, M. M. (2013). Some physic-chemical properties of cashew nut (Anacardiumoccidentale) and palm kernel (Elaeisguineensis) oil using straight run gasoline. International Journal Science and Engineering Investigations, 2 (20), 82-84.

[19] Neilson, S. S. (1994). Introduction to the chemical analysis of foods. Chapman and Hall, New York, pp. 93-208.

[20] Egbebi, A. O. (2014). Comparative studies on the three different species of melon seed; (Ctrulusvulgaries, Cucumeropsismanni and Leganariasiceraria). Sky Journal of Food Science, 3 (1), 1-4.

[21] Amo-Tautua, B. M. W. \& Onigbinde, A. O. (2013). Physicochemical properties and fatty acid profiles of crude oil extracts from three vegetable seeds. Pak J Nutr, 12 (7), 647-650.

[22] Afolabi, I. S. (2008). Chemical qualities of oils from some fresh and market vegetable crops within Kwara State of Nigeria. Biokemistri, 20 (2), 71-75.

[23] Nordin, M. F. N. \&Wannahari, R. (2012). Reduction of peroxide value in palm cooking oil using bagasse adsorbent. AmInt J Contemporary Re., 2, 185-191.

[24] Atinafu, D. G. \&Bedemo,B. (2011). Estimation of total free fatty acid and cholesterol content in some commercial edible oils in Ethiopia, Bahir DAR. J Cereals and Oil Seeds, 2, 7176.

[25] Chakrabarty, M. M. (2003). Chemistry and technology of oils and fats. Allied Publishers Pvt. Ltd, pp. 752.

[26] Codex alimentarius Commission(1993). Report of the fourteenth session of the Codex committee on fats and oils, London, $27^{\text {th }}$ September- $1^{\text {st }}$ October, 1993, Alinorm 95/17. Rome.

[27] Fontagne, S., Bazin, D., Breque, J., Vachot, C.,Bernarde,C.\&Rouault, T. (2006). Effects of dietary oxidized lipid and vitamin A on the early development and antioxidant status of Siberian sturgeon (Acipenserbaeri) larvae. Aquacult, 257, 400-411. 
[28] Fakhri, N. A. \& Qadir, H. K. (2011). Journal of Environmental Science and Engineering, 5, 844-849.

[29] Andrew, C., Buba, A. A., Itodo, A. U. \& Etim, E. E. (2012). Thermoxidative degradation of commonly ued vegetable oils: a comparative study. Journal of Emerging Trends in Engineering and applied Sciences, 3 (6), 924-928.

[30] Aremu, M. O. \&Akinwumi, O. D. (2014). Extraction, compositional and physicochemical characteristics of cashew (Anarcadiumoccidentale) nuts reject oil. Asian Journal of Applied Science and Engineering, 3, 33-40.

[31] Hoffmam, G. (1986). Quality control in food industry. Food Science and Technology series of monograghs, $2^{\text {nd }}$ edition, Academic Press, London, 2, 407-504.

[32] Akpambang, V. O. E., Amoo, I. A. \&Izuagie, A. A. (2008). Comparative compositional analysis on two varieties of melon (Colocynthiscitrullus and Cucumeropsisedulis) and a variety of almond (Prunusamigdalus). Research Journal of Agricultural and Biological Sciences, 4 (6), 639-642.

[33] Olaofe, O., Ogungbenle, H. N., Akhadelor, B. E., Idris, A. O., Omojola, O. V., Omotehinse, O. T. \&Ogunbodede, O. A. (2012). Physicochemical and fatty acids composition of oils from some legume seeds. IJBPAS, 1 (3), 355-363.

[34] Duduyemi, O., Adebanjo, S. A. \&Oluoti, K. (2013). Extraction and determination of physic-chemical properties of watermelon seed oil (Citrulluslanatus L.) for relevant uses. International Journal of scientific and Technology Research, 2 (8), 66-68.

[35] Ayoola, P. B. \& Adeyeye, A. A. (2010). Effect ofheating on chemical composition and physicochemical properties of Arachishypogaea (groundnut) seed flour and oil. Pakistan Journal of Nutrition, 9 (8), 751-754. 